\title{
O LAZER COMO AFIRMAÇÃO DA IDENTIDADE NO TIMING DA FINITUDE
}

Recebido em: $18 / 12 / 2018$

Aceito em: 12/10/2019

\author{
Claudia Franco Monteiro ${ }^{1}$ \\ Cristiane Miryam Drumond de Brito ${ }^{2}$ \\ Universidade Federal de Minas Gerais (UFMG) \\ Belo Horizonte $-\mathrm{MG}-$ Brasil \\ Raquel de Magalhães Borges ${ }^{3}$ \\ Universidade Federal de Juiz de Fora (UFJF) - Campus Governador Valadares \\ Governador Valadares - MG - Brasil
}

RESUMO: Este trabalho é fruto de uma pesquisa do Programa de Pós-Graduação em Estudos do lazer e visa apresentar sua fundamentação teórica para um campo etnográfico referente a pessoas no timing da finitude da vida. Para tanto, apresenta as contribuições de importantes pensadores sobre o tema morte $\mathrm{e}$ atividade cotidiana/habituais como afirmação da identidade tais como Morin, Giddens e Kellehear. Propõe uma reflexão sobre o lazer dentro da perspectiva da filosofia existencial e investiga a possibilidade do lazer ser manifesto com um forte sentido de identidade e alinhado aos desejos mais autênticos no tempo da finitude. Mas também busca avançar para reflexões sobre o ser morrente, como um sujeito social e passível de interferências do mercado de consumo e da cultura de massa nas escolhas de atividades de lazer, além de outros determinantes como a condição sociocultural.

PALAVRAS-CHAVE: Atividades de Lazer. Morte. Construção Social da Identidade.

\section{LEISURE AS AN AFFIRMATION OF IDENTITY IN THE TIMING OF END OF LIFE}

ABSTRACT: This work is the result of a research of the Postgraduate Program in Studies on leisure and aims to present its theoretical foundation for an ethnographic field referring to people in the timing of the finitude of life. For that, it presents the contributions of important thinkers on the subject of death and activity as affirmation of identity such as Morin, Giddens and Kellehear. It proposes a reflection on leisure within the perspective of the existential philosophy and investigates the possibility of leisure to be manifest with a strong sense of identity and aligned with the most authentic desires

\footnotetext{
${ }^{1}$ Docente no Departamento Curso Terapia Ocupacional Universidade Federal do triângulo Mineiro

${ }^{2}$ Docente no Departamento do Curso Terapia Ocupacional UFMG e Pesquisadora do Programa de PósGraduação Interdisciplinar de Estudos do Lazer.

${ }^{3}$ Docente no Departamento de Educação Física, Instituto Ciências da vida da Universidade Federal de Juiz de Fora. Pós-graduanda no Programa para Doutoramento em Estudos do Lazer da Escola de Educação Física Fisioterapia e Terapia Ocupacional (EEFFTO) da UFMG.
} 
in the time of finitude. But it also seeks to advance to reflections on being dead, as a social subject and susceptible to interference from the consumer market and mass culture in the choices of leisure activities, as well as other determinants such as sociocultural condition.

KEYWORDS: Leisure Activities. Death. Social Construction of Identity.

\section{Introdução}

É certo que todas as pessoas vivem na iminência da morte, afinal todas tem consciência de que a finitude da vida pode bater à porta a qualquer momento. Neste artigo, adota-se a ideia de iminência da morte tal qual Kellehear (2016) apresenta como "autoconsciência do morrer iminente", que ora ou outra atravessa os pensamentos cotidianos amparados nas construções sociais e culturais que rodeiam os indivíduos e que fazem parte da história da civilização, como as guerras, a violência, as doenças e epidemias, e até mesmo as catástrofes naturais. Mas também aquelas apontadas por Morin (1988), na perspectiva antropológica e descritas nos rituais fúnebres. Situações estas que posicionam os indivíduos numa condição de impotência diante da mortalidade. Não temos controle sobre o tempo de existência de cada um, mas é sabido que a vida pode ser extinta a qualquer momento.

No entanto, existe uma condição que vai além dessa certeza factual, que é a condição do indivíduo que se encontra na finitude. Neste caso, a sensação da morte iminente pode eclodir de várias situações advindas da inconstância ou falta de prontidão para responder às demandas da vida cotidiana colocada à prova por uma frágil condição de saúde. Esta condição atravessa um período de tempo difícil de ser previsto/calculado e é compreendido como o timing da finitude. A forma como esse momento será vivenciado está diretamente relacionado com a construção biográfica do sujeito no decorrer da vida. 
$\mathrm{Na}$ vasta experiência de Kubler-Hoss ${ }^{4}$, após testemunhar o timing de finitude de seus pacientes, percebeu que aqueles que mais sofriam de temor da morte relatavam não terem vivido bem e profundamente suas vidas. Além de demonstrarem a necessidade de compartilhar sua realidade de maneira franca e o desejo de não serem tratados como moribundos. Em uma de suas publicações ela aconselha: "se você viver bem, jamais terá que se preocupar com a morte" (KLUBER-ROSS, 2015, p.29). No entanto, essa constatação não deve desconsiderar as possíveis influências socioculturais como fatores determinantes para se levar uma vida de qualidade. É certo que cada um tem uma forma singular de lidar com os desafios da vida, apoiados nos valores e crenças pessoais, porém, circundados por influências sociais, culturais que potencializam ou dificultam as possibilidades de autorrealização.

Morin (1988, p.17) aponta para a condição social e afirma que todo ser humano vive, apesar da morte. Em seu ponto de vista "o homem aprende a viver com ela e apesar dela". Trazendo um olhar social a este acontecimento, pontua que, dependendo da condição social do indivíduo, a morte sempre foi uma condição presente. A pobreza, a miséria, a invisibilidade, talvez coloquem as pessoas em um lugar mais próximo da morte que da vida. Mas também há que se considerar que se a morte é tão presente na vida dos menos favorecidos, é possível que estes tenham desenvolvidos mecanismos e estratégias de viver ou sobreviver a ela apontando para comportamentos de pulsão de

\footnotetext{
${ }^{4}$ Internacionalmente reconhecida pelo seu trabalho de aconselhamento com pacientes na fase terminal em todo mundo e defensora da importância de ouvir e ser honesto/ético com a pessoa que esta na fase de finitude da vida. Sua notável contribuição especialmente para o campo dos Cuidados Paliativos encontrase nas seguintes publicações:

KÜBLER-ROSS, Elisabeth. Sobre a Morte e o Morrer. 4. ed. São Paulo: Martins Fontes, 1969.

KÜBLER-ROSS, Elisabeth. Morte - estágio final da evolução. 2. ed. Rio de Janeiro: Record, 1975.

KÜBLER-ROSS, Elisabeth. Perguntas e respostas sobre a Morte e o Morrer. São Paulo: Martins Fontes, 1979.

KÜBLER-ROSS, Elizabeth. A morte: um amanhecer. São Paulo: Pensamento, 1991. [2]

KÜBLER-ROSS, Elisabeth. A roda da vida: memórias do viver e do morrer. Rio de Janeiro: GMT, 1998. Social Construction of Identity
} 
vida. Seja como for, todos os indivíduos na condição de seres humanos finitos, tem uma libido que os impulsiona ora para a vida e ora para a morte, e que se conecta com nossas produções de vida cotidiana.

Porém, este estudo problematiza o desempenho de atividades, trazendo as contribuições de Morin (1988), que afirma que, quanto maior a nossa consciência da morte, maior será a necessidade de afirmar nossa identidade, e encontrar a razão para as atividades cotidianas: a atenuação da angústia pela consciência da mortalidade. Giddens (2002), avança nesta reflexão e aponta as atividades como um hábito cotidiano necessário e apresenta conceitos como autoidentidade e seus desafios na modernidade tardia, tais como a sensação de incerteza e morte. Ambos os autores chamam a atenção para a construção da identidade no decorrer dos afazeres cotidianos, muitas vezes distantes da consciência e autenticidade do ato, meramente mecânico, pouco crítico e sem afinação com os próprios talentos. Neste panorama, as atividades de lazer também exigem uma análise mais apurada, já que tem sido alvo do mercado de consumo, atribuindo a estas um valor massificado.

[...] com práticas compulsivas, ditadas por modismos, ou denotadas de status [...] quando poderia ser e é "a possibilidade para tomada de consciência capaz de romper a letargia administrada pelo habito a partir do reconhecimento do absurdo que se interpõe sobre nossa condição existencial (PUKE; MARCELLINO, 2013, p. 24).

Na perspectiva existencial e pensando o lazer analogamente às contribuições de Kubler Ross, pode-se dizer que a vivência de um lazer carregado de sentidos e o mais perto de nossa autenticidade para a formação da autoidentidade, pode ser uma experiência significativa para dar sequência biográfica no timing da finitude.

Desta forma, este estudo parte inicialmente das contribuições de Morin (1988) e o pensamento complexo, e sua aplicabilidade para o tema da morte que notoriamente ele desenvolveu; além dos caminhos percorridos pelo autor para apresentar relações entre a 
consciência da morte e a afirmação da identidade. Seguindo sobre o tema identidade e morte, são apresentadas as contribuições de Giddens (2002) sobre o conceito de autoidentidade na modernidade tardia e sua aplicabilidade no contexto da morte iminente. Posteriormente, Kellehear (2016), um autor contemporâneo da morte social auxilia ampliar as reflexões sobre identidade e o timing relacionado ao período da finitude.

Todo este arcabouço teórico converge para o lazer a partir da perspectiva do pensamento existencial como uma forma promissora de apresentar o lazer manifesto em atividades de autorreflexão, autenticidade e autoexpressão no decorrer da vida e especialmente na finitude. No entanto, sem desconsiderar o ser morrente, como um sujeito social passível de interferências do mercado de consumo e da cultura de massa nas escolhas de atividades de lazer, além de outros determinantes como a condição sociocultural, ainda que, no período de sua finitude.

\section{A Morte na Perspectiva da Teoria da Complexidade}

O caminho da morte deve levar-nos mais fundo na vida, como o caminho da vida nos deve levar mais fundo na morte

(MORIN, 1988) .

Falar sobre a morte fundamentada no pensamento complexo, é deparar-se com uma feliz e desafiadora jornada. O filósofo Morin, pensador do paradigma da complexidade, apresentou sua teoria na década de 70 e colocou em cheque toda uma corrente de pensamento do século XX, até então pautada na simplificação do pensamento e no método de compartimentação do objeto de pesquisa que buscava, dessa forma, o controle da realidade. No entanto, o pensamento complexo propõe lidar com o real, “(...) de com ele dialogar e negociar” (MORIN, 2006, p.6). 
Neste ponto, é reforçado o desafio de assumir um posicionamento que ultrapassa a tradicional formação reducionista do campo da saúde, área de formação das autoras deste artigo. Mas, sobretudo, pelo fato do pensador não negar a simplificação ou o reducionismo para aproximarmos ao "real conhecimento". Ele apresenta de maneira consistente uma série de argumentações que encoraja a não encerrar neste tempo/espaço de conhecimento, mas avançar para além desse estado de coisas que sofrem influências co-determinantes, tal qual todo objeto de conhecimento.

Desta forma, este autor impulsiona ao exercício do pensamento conjuntivo somando conhecimento de vários campos disciplinares. Enfim, o pensamento complexo não é um caminho de complicação, mas um método para revelar a complexidade do real.

\begin{abstract}
A complexidade é a união da simplificação e da complexidade [...]. O complexo volta, ao mesmo tempo, como necessidade de apreender a multidimensionalidade, as interações, as solidariedades, entre os inúmeros processos [...]. Assim, o pensamento complexo deve operar a rotação da parte ao todo, do todo à parte, do molecular ao molar, do molar ao molecular, do objeto ao sujeito, do sujeito ao objeto (MORIN, 2001b, p.433).
\end{abstract}

Queremos nos ater ao ponto mencionado pelo autor "as solidariedades, entre os inúmeros processos", pois acreditamos existir um movimento dialógico no campo da solidariedade ou uma conversa entre os saberes quando lançamos um olhar multidimensional ao sujeito e objeto de estudo. A multidimensionalidade envolve o estudo do objeto ou as relações entre o objeto e o sujeito sem negligenciar os efeitos desse fenômeno de interação.

A multiplicidade de interações, retroações e reorganizações que constituem o humano e sua subjetividade não podem ser abordadas dentro de um referencial linear. Por isso, o pensamento complexo revela uma razão que dialoga com a multidimensionalidade do humano, enquanto ser bio-antropo-psico-social e com as relações que 
compõem o real, incluindo o continuum ordem-desordem (MORIN, 2005, p.291).

Pensa-se nas interações em relações dialógicas que se complementam em seu antagonismo. E é nesse contexto que a teoria de Morin (1988) apresenta-se como uma fonte de conhecimento que abraça o tema deste estudo, discorrida brilhantemente ao escrever $\boldsymbol{O}$ homem a morte. É possível que a angústia de pensar na morte muitas vezes se dê por presumi-la como aniquilamento da vida, por isso ser um assunto tão paradoxal para o ser humano que sempre buscou sua imortalidade, formas de sobrepujar sua própria sentença de morte. É curioso que a morte esteja muito próxima de todos os indivíduos como um fenômeno inerente. Do ponto de vista biológico, o autor faz uma interessante afirmação ao considerar o sistema orgânico como um sistema bioantropológico. $\mathrm{Na}$ medida que vivemos a destruição interna de morte celular permanente, também vivemos a sua renovação. Significaria a autopoiesis: um estado de autoprodução através da morte, como o movimento incessante de morte e renascimento celular, de caos e reorganização orgânica. Assim como nas células, na vida humana a sociedade encontra-se também em estado de autoprodução permanente através da morte dos seus indivíduos (MORIN,1988).

Pensar o paradigma da complexidade aplicado à vida e à morte é remeter ao movimento intracorpóreo de organização/desorganização/reorganização, que vai além de simples analogia. Trata-se da "lei" do ciclo animal, amiúde apontado como antropobiologia (MORIN,1988,p.10). Com o tempo todo os indivíduos são levados a infringir os desafios impostos em várias experiências humanas que compactuam com o ritmo de morte e renascimento de etapas e ciclos vitais. 
Todo romper de um novo ciclo vital: infância/adolescência/adulto/velhice conduz à experiência de superação de períodos de morte e renascimento. Diz respeito a mudanças internas celulares/ corticais /biológicas que, concomitantemente, geram mudanças externas que respondem a nova forma de ser e agir para o mundo. Não diferente disso, Morin se refere à ordem sociológica humana quando aponta que a reorganização social é incessante e ocorrem por meio de desordens, antagonismos e conflitos que simultaneamente minam a existência e mantém a vitalidade (MORIN,1988,p.16).

Segundo seu pensamento, na história da civilização as sociedades rompem em ciclos de vitalidade, após superar períodos de grande tensão. E sustenta que, a sequência de experiências de reorganização permanente da sociedade se dá, “(...) pois a mesma funciona não apenas apesar da morte e contra a morte, mas que esta existe enquanto organização, pela morte, com a morte e na morte" (MORIN, 1988, p.10).

\section{A Dialética entre Traumatismo, Consciência e Imortalidade}

O modelo de morte e renascimento concebido pela sociedade desenvolveu diversas combinações sobre as crenças e ideologias da morte na qual Morin (1988) chamou de "Triplo dado sobre a morte", sendo estas: o traumatismo da morte, a crença na imortalidade e, por fim, a consciência da morte. Mas é interessante mencionar que o autor discutiu a teoria do Triplo dado da Morte de forma dialética, explicando como cada uma delas se interrelacionam dinamicamente. O traumatismo da morte é evidenciado na história da civilização nos rituais fúnebres que cumpre um papel na qual o autor descreve como: "um conjunto de práticas que simultaneamente consagram e determinam a mudança de estado do morto, institucionaliza um complexo de emoções: 
reflete as perturbações profundas que uma morte provoca no círculo dos vivos" (MORIN, 1988, p.26). Ele apresenta o funeral como um acontecimento que evidencia a morte como condição inelutável, mas ao mesmo tempo influenciada pela crença da imortalidade. Tal crença foi expressamente manifesta por civilizações arcaicas também nos rituais fúnebres que ainda permeiam a contemporaneidade. Por exemplo, no período pré-histórico, práticas de conservação do cadáver implicavam no prolongamento da vida. Na atualidade, são observadas várias crenças que buscam favorecer a sobrevivência do morto, tais como: a crença de se tornar um espectro corpóreo, sombra, fantasma, ou ainda a crença em seu renascimento. A sociedade não nega a morte, mas a compreende como um acontecimento da vida, ou seja, o ideal de imortalidade, não rejeita a consciência da mortalidade.

Porém, há uma questão não menos importante que o ideal de imortalidade ou consciência da morte que seriam "as perturbações causadas pela morte na vida humana" (MORIN, 1988, p.112). Essas perturbações podem ser vivenciadas no processo de morte e luto, e trazem consigo uma conotação culturalmente impressa nessas experiências. O filósofo Ricoeur (2012), ao discutir sobre sua própria morte, aponta para a morte compreendida culturalmente como um "Mal Absoluto". Morin (1988) fala dos mitos arcaicos que influenciaram no sentido de seu "malefício" ou "feitiçaria". Diante disto, o pensamento de Ricoeur (2012) complementa-se com o de Morin (1988) ao se referir ao horror da morte na sociedade. Nesta concepção, a morte não se separa do mal, pois a humanidade percebe sua existência ameaçada por projetos de extermínio, sejam em guerras, doenças contagiosas ou catástrofes naturais. Ou ainda, lembra-se de sua finitude, ao experienciar um ato fúnebre ou o luto. Desloca-se, assim, o sentido de morte para morte violenta, designada pelo maligno ou por um Deus punitivo. 
Mas isso não basta: é preciso que todas as mortes- as mortes por doença, por velhice, logo as mortes por exaustão da vida - sejam assimiladas à morte violenta: então o extermínio volta para o contágio, que por sua vez absorve em suas margens a morte banal (RICOEUR, 2012, p.25).

No entanto, Ricouer desvela o mal da morte e aponta que a morte não é má, e sim, a aparência a ela atribuída, afinal, os extermínios e as doenças não pertencem à morte e sim à maldade. Todas essas questões são entendidas como formas de consciência da morte que trazem o sentimento de horror pela morte, mas aponta que na verdade, o que esta por trás desse terror é o medo da perda da individualidade. É possível que a consciência da morte venha a fortalecer o senso de identidade, do sentido de ser e estar no mundo. Morin (1988) lembra que as crianças, ao iniciarem sua formação de identidade, desencadeiam, a partir de então, a angústia da morte pela consciência da finitude. Também, para aquele que vive a intensa sensação de morte, seja por doença, acidente, ou qualquer outro tipo de situação, vive a intensidade da afirmação da individualidade, ainda que no plano real ou idealizado, mas no profundo desejo de reafirmação do seu eu. Esta é uma das primeiras conclusões de Morin em sua publicação "O homem e a morte": quanto maior a consciência da morte, maior será a afirmação da individualidade. Portanto, para quem está vivendo a finitude, o último resíduo da consciência poderá ser a do ego e de seu desejo de afirmação.

\section{A afirmação do Eu no Contexto da Morte Social}

A discussão sobre a afirmação da individualidade é apresentada como um processo dinâmico, que, ora projeta o individual para além do coletivo e ora projeta o coletivo para além do individual. Esse fenômeno pode ser observado no contexto da morte social, em situações de guerra, do morrer pela pátria ou morrer por uma causa. 
Assim, no momento da tensão heroica da batalha, tudo que há de humanidade na morte (consciência, traumatismo, imortalidade) pode ser abolido com o próprio humano na solidariedade animal, na luta bestial, na obsessão pura da agressão e da defesa (MORIN, 1988, p.41).

Nesse sentido da guerra, o desertor seria aquele que quer fazer valer sua individualidade, ainda que seja acusado de traidor da pátria.

Seguindo a linha do civismo podemos compreender que em uma sociedade evoluída, em que a cidade estaria a serviço dos cidadãos, em troca o indivíduo poderia abdicar-se conscientemente de sua primazia em proveito da cidade, em um sistema diferente de submissão incondicional; o que difere da guerra, em que a cidade entende que se alimenta da soma das individualidades e não em detrimento dessas. Nesse tipo de sociedade haveria troca de satisfação entre os cidadãos e a cidade - o cidadão empresta suas virtudes e a cidade reconhece. Haveria uma importância empregada à expressão da individualidade, uma forma de subexistir na memória coletiva: o valor da vida. Por outro lado, o sujeito que não se sente pertencente à universalidade característica de uma cidade dita cosmopolita, que não acolhe as particularidades do sujeito, este estará arriscado a cair na solidão, não se esquecerá da própria morte. Neste caso, há o risco do suicídio que seria em decorrência do vazio social.

Morin (1988) estende essa discussão às divisões de classes exemplificando nas relações rei/súditos, senhor das terras/escravos/feudos. O rei, que representa o Estado tem a identidade única do poder soberano quase inalcançável, detêm o poder sobre a massa. Olha para os súditos como objeto, assim como o senhor concebe seus escravos, sendo o último mero apêndice da terra, servidores, trabalhadores oprimidos. Quanto mais o senhor ou o rei afirmar sua individualidade, mais será negado outras individualidades. Na história social das classes, a cultura do senhor se expande a partir 
da incultura do escravo. Assim como na história da individualização, sua expansão muitas vezes é afirmada a partir da desinvidualização do outro. É claro que, o escravo irá almejar a sua individualidade que será sempre negada pelo senhor. A identidade do senhor é o modelo a ser seguido, ela desperta o desejo da emergência econômica à superfície social, ainda que não seja o melhor modelo a ser seguido.

E é dialeticamente que o temor a morte e o direito à imortalidade se vão estender aos oprimidos, às mulheres e aos escravos, à medida que estes conquistam a propriedade da sua pessoa, que emergem econômica e juridicamente à superfície social (MORIN, 1988, p. 51).

Por outro lado, a não consagração dos planos de vida, dentro dos valores capitalistas, pode ser uma grande razão para questionar-se o sentido da vida, especialmente em situação de morte iminente. Do ponto de vista social, a crise existencial do indivíduo desassistido socialmente, apresenta-se no desejo de todo homem de desfrutar do estado de glória cidadã, em que há uma exaltação individual pelo serviço insigne prestado à pátria tornando-se socialmente imortal. Ao transcrever essa questão macrossocial para contextos microssociais, quando um indivíduo tem a oportunidade de "emprestar" suas virtudes para a sociedade, integrando uma causa particular há uma causa comum, há a consagração de sua individualidade, um instante glorioso, levando-o a um estado de felicidade. Ao contrário, o indivíduo esquecido pela sociedade, com dificuldade de exercer seus propósitos pela falta de oportunidade em função das condições sócio-econômico-culturais a ele impostas, sentirá sua individualidade isolada no mundo. Este, por sua vez, pode contestar a sociedade, que desligada de sua vida não lhe pode fazer esquecer a morte. Tratam-se aí de situações de indivíduos que, no exercício da cidadania, são mais vulneráveis às adversidades sociais 
e menos propensos a fazer valer suas escolhas, de viver e transmitir seus talentos pessoais, e, desta forma, menos propensos a viver momentos gloriosos e de felicidade.

Bem provável que as condições sociais favoráveis e democraticamente garantidas pelo Estado a todas as classes, viabilizariam qualidade de vida a todos os indivíduos, independente de gênero, idade e etnia, tornando-os os maiores protagonistas e responsáveis pelos caminhos que almejariam para sua felicidade. E, desta forma, a máxima "viver bem, para morrer bem" seria uma condição mais palpável tornando o findar da vida menos aterrorizador. Seria toda a distância que separa a consciência da morte da aspiração à imortalidade. Diferente das mortes em massa, a morte de um indivíduo que deixou suas marcas pessoais, reconhecido pelas pessoas em seu entorno como um sujeito íntimo e amado, trará maior sofrimento para aqueles que ficam e deparam-se frente a frente com a realidade de suas próprias finitudes. Mas, importa a reflexão para trazer à luz da consciência sobre a morte e afirmação da individualidade: que na história do seu desenvolvimento na humanidade, esta se efetuou com base e mediante a mais brutal desindividualização de outrem (MORIN, 1988).

\section{A Morte e o Ego}

Morin (1988) identifica a consciência da morte no campo da relação social, mas também se apropria dos estudos de Freud para apontar que a consciência da individualidade no campo da psique se reforça na medida em que se suprime a identidade do outro. Esse processo inicia-se no indivíduo quando criança e seu desejo em "matar" os pais na medida que se torna consciente de sua individualidade.

O ser humano, então, inicia a partir da infância uma jornada em busca de reconhecimento, prestígio e honra. "Esse desejo vai colidir com o das outras 
consciências de si, numa luta de morte" (MORIN, 1988, p. 65). A afirmação da identidade tende a acontecer em detrimento da desidentificação do outro. Sendo uma autossuperação em detrimento de toda a espécie, diferenciando o ser humano das outras espécies animais. Os animais não eliminam os de sua espécie se não for por razão dos códigos de sobrevivência da própria espécie. Já os seres humanos, matam o seu semelhante por sadismo, vaidade, por considerá-lo ameaça à sua individualidade. Esta também é uma falsa aspiração à imortalidade, mas que, jaz tão logo o assassino presencia o cadáver, logo se recordando de sua subindividualidade expresso na identidade já reconhecida de seu senhor, dono de si mesmo, já que é dono de propriedades e bens. Por outro lado, quando se deseja eliminar o outro, ou quando isso acontece, algo paradoxal pode ser observado, pois, aquele que mata corre o risco de ser morto. Morin (1988) atribui isso ao campo do instinto animal que enxerga o outro como ameaça e deve ser eliminado.

Por outro lado, esse risco também aparece nas guerras, onde o cívico supera o individual, ou nas relações do sujeito que mata por efeito de sua crença religiosa, questões essas que superam o individualismo a fim de honrar um coletivo. Portanto, também nos arriscamos a morte por amor, por êxtase, por vaidade, por sadomasoquismo, por loucura, por felicidade...ao derradeiro sentimento que transpira da última atitude daquele homem (MORIN, 1988, p. 68).

Isto pode ocorrer por um coletivo, e muitas vezes, pelo próprio indivíduo, suas próprias ideias, pensamentos e credos, e desta forma, não renegando a ele mesmo. Mais uma vez o ego quer seu lugar na eternidade dos vivos.

Apesar do homem almejar sua imortalidade, ele compreende e tem consciência de sua morte e da condição de inelutabilidade.

Com efeito, embora conhecendo a morte, embora traumatizados pela morte, embora privados dos nossos mortos amados, embora certos de nossa morte, vivemos igualmente cegos à morte, como se os nossos parentes, os nossos amigos e nós próprios não tivéssemos nunca que morrer (MORIN, 1988, p.60). 
O ser humano manifesta sua cegueira com relação à morte na sua vida cotidiana não dando espaço para pensar nela. Este fato apresenta-se justificado na busca de atividades consideradas vitais ao ponto de fazê-lo esquecer a própria morte. Geralmente atividades que representem um ideal, um valor que traga sentido à existência. Algo que quase supõe ser de extrema significância ao sujeito e que fortaleça sua identidade social, sua virtuosidade cidadã.

O facto de aderir à atividade vital elimina todas as ideias de morte, e a vida humana comporta uma parte enorme de despreocupação pela morte; a morte esta frequentemente ausente do campo da consciência, que aderindo ao presente, afasta tudo o que não for o presente, e, nesse plano, o homem é evidentemente um animal, isto é, dotado de vida. Nessa perspectiva, a participação na vida simplesmente vivida implica em si mesma uma cegueira à morte (MORIN, 1988, p.60).

Nesse sentido, parar de fazer as coisas é não fortalecer a identidade que se reveste de significados e nos torna imortal. A ociosidade seria um pacto com a morte, é a porta para pensar na finitude e quanto menos faço, menos marcas eu deixo, menos pegadas marcam minha caminhada. "A ociosidade é um veneno do amor a si mesmo" (MORIN, 1988, p.60). O autor trata essa questão da ociosidade com certa ironia, já que compreende que a identidade constituída no plano do fazer-se cidadão honrado, comunga de um reconhecimento da identidade aprisionada aos benefícios econômicos e ao aumento do poder sobre outras pessoas, posição esta claramente apresentada no decorrer de sua obra. Além disso, em 1935, já encontramos contribuições do filósofo Russel em suas reflexões sobre a importância do ócio concebendo-o como o tempo necessário de promover tensão com o pensamento moderno de "culto à eficiência" que desqualifica as oportunidades de autoexpressão onde "permite ao indivíduo avaliar a 
qualidade de sua experiência, bem como o valor do próprio conhecimento" (RUSSEL, 2002, p.8).

Morin (1988) segue seu raciocínio e aponta que existe uma fronteira entre a consciência da morte e o plano inconsciente, em que a morte encontra-se no plano da negação, o que distingui do plano de "não existir" apontado por Freud. Essa fronteira é estabelecida entre o ego (a afirmação da individualidade) e o id que está ligada ao plano animal, intuitivo e ao instinto de sobrevivência, para onde o ego se estende e exerce forte influência. O homem busca em sua diversão esquecer-se de si mesmo e assim esquecer-se da morte. $\mathrm{O}$ id é o que mantém o homem sempre inconsciente de sua morte, assim como os animais. Sendo assim, Morin (1988) afirma que essa "animalidade" é a própria vida, e, nesse sentido, a obsessão da morte é uma "diversão" da vida. A negação da morte seria um mecanismo psíquico necessário para nos mantermos sãos, desde que não corramos o risco de cair em um fazer obsessivo produto do instinto de sobrevivência, o medo recorrente da falta, de não conseguir o necessário para nos mantermos vivos. Esta condição seria de propriedade do id, que quando ameaçado, pode ser minado pela ideia da morte e/ou enlouquecer. Por outro lado, quando se tem uma condição egoica atrofiada, a individualidade passa a não ser nutrida pelo desejo obcecado da imortalidade, ou seja, ainda que se mantenha o instinto de sobrevivência operado pelo id, a consciência da morte não causa horror paralisante para vida. O medo e não medo opera no indivíduo em um estado menos ansiogênico para com a morte e vida futura. Esta é a condição de "vida una", ou seja, de viver consciente da morte, mas em plena adesão pela vida. Essa condição de boa convivência com a consciência da morte é descrita por Ricoeur, um filósofo que ao final da vida, escreveu sobre o sentimento de luto e júbilo com relação a sua morte: 
Esse luto da representação, [...] se revela como a condição de uma experiência essencial da bondade do viver, seja na forma de um apetitoso desejo de existir que revida com veemência a ameaça vital, seja na forma do desapego e de uma despreocupação consigo repleta de gratidão. [...] ]apetite de viver colorido por certa despreocupação que chamo de júbilo (RICOEUR, 2012, p. 10).

Parece haver um possível estado de consciência de finitude ou inelutabilidade com a morte, sem permitir-se ser devorado pelo medo e nem congelar-se para a vida. Tal estado estaria livre da ansiedade que move os indivíduos para "fazeres" automatizados, distanciados de sentidos e significados. Destaca-se a palavra “essencial”, que acompanha Ricoeur em sua reflexão no seu processo morrente, em que na luta contra o tempo, reconhece a "emergência do essencial" na qual não atentamos na vida, ainda que todos nós estejamos sujeitos a um findar em um tempo próprio que nos é desconhecido. Buscar fazer o essencial seria a "mobilização dos recursos mais profundos da vida para continuar se afirmando" (RICOEUR, 2012, p.13). Neste plano o ego trabalhará conjugado com o id e o superego. O homem não está cego com relação à morte, mas consciente de viver o risco de morte. Nesta modalidade, o indivíduo emprega um valor moral à vida e à individualidade, mas adere a um plano maior de existência.

Morin (1988) lembra que o efeito que a vida expressa em participações sociais realizadas pelo homem pode ser tão poderoso a ponto de esquecer-se de si mesmo, em um desapegar-se de si e de sua morte, ainda que estas participações ofereçam o risco de morte. Essas participações podem ocorrer no âmbito lúdico, moral e social. Seria viver intensamente a vida a ponto de morrer pela vida. Poderíamos neste ponto comparar a situação de mergulho nas grandes paixões, que ainda que nos ofereçam riscos, nos despojam do medo para nos depararmos com as emoções da experiência que ela nos 
proporciona. Seria a busca de uma realidade que nos ultrapassa também movido pelo desejo da autoafirmação rumo à autorrealização quando em estado consciente das escolhas.

Ou seja, o risco de morte implica a participação do indivíduo e que pode dominar seu medo de morte. Não seria aí uma receita para viver, mas aponta para caminhos de pulsão de vida expressa nos afazeres cotidianos. Podemos entender nesse ponto, um sujeito adaptado à ideia da sua finitude e que ao mesmo tempo, goza de uma vida plena de atividades significativas.

Neste ponto, a complexidade da vida e da morte é compreendida a partir do significado da individualidade nesses contextos: "a afirmação da individualidade que rege de forma simultaneamente global e dialética a consciência da morte, o traumatismo da morte, a crença na imortalidade" (MORIN, 1988, p.34).

\section{Identidade: Questão de Vida ou Morte}

A afirmação da individualidade é uma forma de lidar com a consciência da morte, ainda que, em dado momento da vida, ela nos traga a sensação do horror, o medo da aniquilação. Nesse sentido, a identidade visa um caminho de demarcação de um ideário ou porção identitária em busca do "ser social". Mas, pode haver a hora que essa identidade deserta do social, de um coletivo que partilha de uma mesma bandeira, para seguir seus próprios passos. Seria o momento de compreender-se cidadão do mundo atribuído de talentos pessoais reconhecidos ou não pelo coletivo. Essa identidade constituída parece referir-se àquela em que o "ser" desvencilhou-se do "ter" fruto do pensamento moderno vigente. A soma do id e superego ao ego, numa consonância na qual, nessa modalidade, o indivíduo emprega um valor moral à vida e à individualidade, 
ainda que consciente da morte, mas adere a um plano maior de existência. Sem isso, a afirmação da identidade pode configurar uma prolongada e muitas vezes interminável tentativa de ascensão social a partir da apropriação de bens capitais que imprime um padrão competitivo de "ser" a partir do "ter", e de identificação de uns em detrimento da desindentificação de outros resultados das forças de classes e sujeitas culturalmente às diferenças de gêneros, raças e etnias. Morin (1988) apresenta a atividade ou afazeres cotidianos como forma de afirmação identitária e uma maneira estratégica e nem sempre consciente do homem superar o horror da morte. Porém, temos o risco de cair em uma armadilha: o fazer imbuído da fuga do horror da morte e de um tempo negado para pensar na finitude e na inconstância do nosso estado de ser e estar no mundo, ou ainda, anestesiar-se em atividades e escolhas, muitas vezes desenfreadas, em um leque de opções incessantes características de nossa modernidade globalizada. Discutir questões da identidade requer um caminho distinto daqueles constituídos a partir dos avanços trazidos nas reflexões sobre identidades e subjetividades na modernidade como Rolnik $(1997)^{5}$ com indispensáveis contribuições. Porém, esta pesquisa enfatiza a afirmação da identidade no contexto da morte entrelaçada ao conceito de autoidentidade.

Quando Morin fala sobre a identidade do sujeito em sua obra A cabeça bem feita, sua ideia foi apresentar o sujeito não apenas como ator, mas como autor "capaz de cognição/escolha/decisão" (MORIN, 2001a, p.127). A autonomia do sujeito não diz respeito a uma liberdade absoluta, pois sendo seres sociais "só podemos ser autônomos a partir de uma dependência original em relação a cultura, em relação a uma língua, em relação a um saber" (MORIN, 2001a, p. 118). No entanto, ele lembra que na estrutura identitária, em que a um só tempo é possível estabelecer a diferença indissolúvel entre o

\footnotetext{
${ }^{5}$ Suely Rolnik no livro intitulado Cultura e subjetividade - Saberes Nomades(1997), apresenta as tensões entre a desestabilização exacerbada advindas do mundo moderno e a persistência da referência identitária, além de reflexões sobre identidade e subjetividade.
} 
eu (subjetivo) e o "eu" (sujeito objetivado), o sujeito deve sempre abrir espaço para reflexões sobre a ideia de liberdade e autonomia, fazendo uso de sua capacidade cerebral e intelectual de conceber e fazer escolhas; além da possibilidade de operar essas escolhas dentro do meio exterior e da organização cultural que muitas vezes quer ditar nossos pensamentos. "Este princípio comporta a capacidade de referir ao mesmo tempo a "si" (auto-referência) e ao mundo exterior (eixo-referência) - de distinguir, portanto, o que é exterior" (MORIN, 2001a, p. 121). O princípio que nos conduz à vida social seriam as relações intersubjetivas em uma sociedade que nem sempre está entregue aos determinismos materiais, mas sim a um mecanismo entendido por confronto/cooperação entre indivíduos sujeitos, entre nós e os "eu” (MORIN, 2001a, p.128).

Mas algo maior vem se apresentar como grande desafio na atualidade sobre as distinções do "si" em relação ao externo e desta forma, ao mundo. Giddens traz reflexões a esse respeito, quando coloca as imposições contextuais do mundo moderno e as colisões com a autoidentidade. Este pensador chama a atenção para o mundo moderno que ele conceitua como "alta modernidade" ou "modernidade tardia", em "um mundo em disparada", caracterizado não só pelo ritmo da mudança social, mas também por sua amplitude e profundidade, afetando práticas sociais e modos de comportamento preexistentes (GIDDENS, 2002, p. 22). Não há como discutir sobre autoidentidade, sem considerar a dialética entre as mudanças locais e globais modernas e o intenso conjunto de transformações que esta promove na vida cotidiana.

A autoidentidade constitui para nós uma trajetória através das diferentes situações institucionais da modernidade por toda duração do que se costumava chamar "ciclo-de-vida" [...] Cada um de nós não apenas "tem", mas vive uma biografia reflexivamente organizada em termos de fluxo de informações sociais e psicológicas sobre possíveis modos de vida. A modernidade é uma ordem pós-tradicional em que se pergunta "como devo viver?" (GIDDENS, 2002, p. 20). 
Sem sombra de dúvida que tal pergunta no âmbito dessa pesquisa segue uma reflexão complexa, pois ao pensar em como se deve viver, somos impelidos ou ao menos deveríamos pensar em como vamos morrer. Afinal, quanto maior a consciência da morte, maior a afirmação da identidade e o desejo de tornar-se imortal na memória dos que ficam. Nessa perspectiva é necessário refletir sobre os esforços em orientar nossa autoidentidade sem nos perder nos caminhos dessa construção, que lança mão de uma "liberdade relativa", ameaçada pela organização cultural da alta modernidade e pelo jogo dialético entre o local e global, marcados especialmente pelo modelo de produção e distribuição capitalista, afetando profundamente o estilo de vida de comunidades, sociedades e nações.

\section{Sobre a Identidade e a Morte Iminente}

A alta modernidade e suas instituições modernas afetam diretamente a vida individual e, portanto, o "eu". Segundo Giddens, refere-se a um modo de vida, costume e organização social que emergiu da Europa aproximadamente no século XVII e que deu expansão a quatro formas institucionais: o capitalismo, o industrialismo, a vigilância e o poder militar (GIDDENS, 1991). Estas se interrelacionam e afetam a sociedade como um todo, onde as relações de mercado e consumo marcam as ações humanas desde o contexto local para o global. Nesse contexto o "Eu" não é uma identidade passiva:

Ao forjar suas autoidentidades, independente de quão locais sejam os contextos específicos da ação, os indivíduos contribuem para (e promovem diretamente) as influências sociais que são globais em suas consequências e implicações (GIDDENS, 2002, p. 9).

Nessa dialética, a autoidentidade é vista como um projeto reflexivo do eu que necessita constantemente revisar a própria biografia e o esforço por sua coerência no 
trajeto tempo/espaço da existência. O que antes, em nossas sociedades tradicionais, caracterizadas por um referencial protetor, consistiam em transições entre os ciclos vitais demarcados entre ritos de passagem, atualmente, requer "um processo reflexivo de conectar mudança pessoal e social” (GIDDENS, 2002, p. 37). A vida social moderna é atravessada por práticas sociais que precisam constantemente ser examinadas dado o alto fluxo de informação que renova as próprias práticas (GIDDENS, 1991, p.45). Exige maior organização psíquica do sujeito nos períodos de mudanças ou transições da autoidentidade denominada segurança ontológica.

A segurança ontológica seria amparada por aspectos cognitivos e emocionais adquiridos no inicio da vida e que permitem um desenvolvimento psicológico que "transporta o indivíduo pelas transições, crises e circunstâncias de alto risco" (GIDDENS, 2002, p. 41). Para tanto, Giddens (2002) lança mão de teorias como de Erickson e Winnicott ao tratar do tema sobre confiança básica na primeira infância. Seria a partir dessa primeira experiência de confiança que emergiria inconscientemente a fé, coragem e esperança como elementos de grande importância para a autoidentidade. Esses elementos seriam frutos da experiência de separação do pai e da mãe como essencial processo para a formação da consciência da identidade advinda da aceitação da ausência.

A confiança que a criança, em circunstâncias normais, investe nos que cuidam dela-[...]- pode ser vista como uma espécie de inoculação emocional contra ansiedades existenciais - uma proteção contra ameaças e perigos futuros que permite que o indivíduo mantenha a esperança e a coragem diante de quaisquer circunstâncias debilitantes que venha a encontrar mais tarde (GIDDENS, 2002, p. 46). 
Contra a ansiedade existencial acentuada pelo contexto da alta modernidade, a manutenção de hábitos e rotinas adquiridos nos primeiros cuidados da infância, atuaria como "efeito calmante" dentro de experiências constitutivamente organizadas.

A disciplina da rotina ajuda a constituir um "referencial" para a existência, cultivando um sentido de "ser", e sua separação do "nãoser", que é um elemento de segurança ontológica. Inclui orientações em relação ao aspecto do mundo dos objetos que carregam resíduos simbólicos para a vida posterior do indivíduo (GIDDENS, 2002, p. 42).

Compreende-se dessa forma, que qualquer escolha por uma atividade cotidiana, ainda que pareça despropositada, pode estar repleta de significados para aquele que a executa. Mas há que se buscar uma consciência prática dos afazeres ancorada no cognitivo e emocional, lembrando essas dimensões como indispensáveis à vida, pois “permite o sujeito não ser ator, mas sim autor da própria vida, capaz de cognição/escolha/decisão" (MORIN, 2001a, p. 127). A autonomia da escolha dos afazeres cotidianos, se não amparados pela consciência prática, correm o risco de serem esmagados pelos determinismos hegemônicos de consumo, transmitidos de forma massiva especialmente pela mídia, podem gerar "ansiedade sobre os riscos implícitos nos afazeres da vida" (GIDDENS, 2002, p. 43). A segurança ontológica, neste caso, funciona como um "casulo protetor" e que este, passível de ser rompido, dependendo da contingência da vida, das pressões externas, pode passar por uma invulnerabilidade relativa, mas com pré-disposição psicológica capaz de voltar ao ponto de estabilidade. Ou seja, a segurança ontológica "difere da adesão cega ao habito, ao contrário, um compromisso cego com rotinas estabelecidas, venha o que vier, é sinal de compulsão neurótica" (GIDDENS, 2002, p. 43).

Mas talvez haja uma linha tênue entre o que se compreende entre uma "atitude natural" dos afazeres cotidianos e a consciência prática que permite o sujeito expressar 
o "ser" em seus afazeres, tendo em vista expressar o sentido de sua existência. Sem a consciência prática, sem o empreendimento cognitivo e emocional para orientar as escolhas do que se faz cotidianamente, o risco de adentrar um cotidiano caótico sujeito a atividades desprovidas de sentidos ou de viver uma rotina desenfreada, não é pequeno.

Nesse panorama podemos evocar dois tipos de sensação de horror mascaradas pelo fazer rotineiro: o de Kierkegaard (1944) lembrado por Giddens (2002) que aponta o horror na perspectiva de ser ultrapassado por ansiedades que atingem a raiz própria de nossa sensação de "estar no mundo"; e de Morin (1988), o horror da consciência da morte, na qual, à medida que se envolve em atividades, menos se lembra da finitude. Mais uma vez confirmando a afirmação provocativa: "a ociosidade é um veneno do amor a si mesmo" (MORIN, 1988, p.60). Creio que essa provocação tenha como pano de fundo a clareza do que o tempo do ócio pode vir a subtrair dos nossos afazeres rotineiros: "o momento do conhecimento que inspira uma concepção da finalidade da vida humana como um todo" permitindo o indivíduo refletir sobre si mesmo e sobre o “ser" para o mundo (RUSSEL, 2002, p. 46).

Essas experiências existenciais, que tensionam o pensamento e podem gerar inquietações, exigem certa dose de coragem, já que faz parte da natureza humana o temor à mudança. Mas, ainda que vistas com conotações que podem variar entre "atitudes heroicas" ou "perda de tempo" no pensamento moderno, são compreendidas por Russel (2002) como “...daquilo que é distintivo do ser humano: o poder de ver, e conhecer, de sentir com magnanimidade e de pensar com entendimento" (RUSSEL, 2002, p.45). O ócio seria uma condição para ampliação do estado de consciência quando este dá lugar às questões existenciais, além do que, ampliam a possibilidade de viver a vida de forma mais criativa, tendo a criatividade como um elemento indispensável às 
práticas de rotina. A criatividade pode ser a chave para "seguir em frente" nos contextos da vida, especialmente naqueles mais desafiadores. Giddens (2002) não conduz suas reflexões para o ócio criativo, mas lembra de que uma vida de afazeres, não deveria ser uma vida desprovida de criatividade. Adverte que a criatividade ou a falta desta dependerá da segurança emocional fornecida pela segurança básica nas relações primordiais. Seus benefícios na vida adulta, conduz a autoidentidade para além da persistência da identidade no tempo biográfico:

[...] a autoidentidade é o eu compreendido reflexivamente pela pessoa em termos de sua biografia. A identidade ainda supõe a continuidade no tempo espaço: mas a autoidentidade é essa continuidade reflexivamente interpretada pelo agente (GIDDENS, 2002, p.54).

A autoidentidade como fruto da modernidade tardia, possui um eu reflexivo caracterizado por uma autoconsciência dos diferentes contextos e culturas que a afeta velozmente, exigindo um exercício de interpretação e reinterpretação de sua pessoidade $^{6}$. Portanto, esse conceito se aproxima ao princípio de Morin (2001a) de autoreferência e exoreferência, que conduz as relações intersubjetivas em uma sociedade entregue a mecanismos entendidos por confronto/cooperação entre indivíduos sujeitos, entre nós e o "eu".

\section{Biografia e suas Demandas Sociais na Vida e na Morte}

\footnotetext{
${ }^{6}$ Termo utilizado na tradução do livro de Anthony Giddens (2002) e que se apresenta como um conceito de "Ser uma pessoa" aplicável ao eu e aos outros. O "eu" aplicável a diferentes contextos característicos de cada cultura.
} 
Primeiramente, esforcei-me em apresentar as contribuições de Morin (1988), especialmente relacionadas à afirmação da identidade como forma de sobrepujar a morte, e ainda, as afirmações relacionadas aos afazeres e a consciência da morte, "quanto mais nos apegamos aos afazeres, menos horror a morte sentiremos". Posteriormente, avancei em direção às contribuições de Giddens (2002), que nos apresenta a autoidentidade e segurança ontológica como mecanismos de manejo para sobreviver biograficamente nos tempos modernos, tempos que nos ronda a sensação de insegurança que pode se aproximar à sensação de morte iminente no campo existencial. Se a autoidentidade sugere um "Ser para o mundo" que trafega na dialética local e global da modernidade sem se perder de si, dado sua característica de ser reflexivo e sustentado pela segurança ontológica, o que dizer do sujeito que não teve oportunidade de vivenciar a segurança primordial no seio do núcleo familiar e que o autor vai chamar de indivíduo ontologicamente inseguro? Ainda que, Giddens não tenha se aprofundado nas relações entre os prejuízos decorrentes da desigualdade social e as condições mínimas de suporte psicoemocional a um indivíduo na primeira infância e decorrer da vida, ele lembra que a própria modernidade com sua produção e distribuição de capital tem sido grande responsável pela "divisão de classes e outras linhas fundamentais de desigualdade, como as que dizem respeito a gênero e etnicidade", distinguindo o acesso de forma desigual para possibilidades de autorrealização e emancipação do eu (GIDENS, 2002, p. 13). Desta forma, famílias destituídas de condições básicas de sobrevivência ou em maior vulnerabilidade social como a pobreza, a fome, a violência, as doenças e/ou a baixa escolaridade, podem estar mais pré-dispostas à insegurança ontológica. Questões voltadas aos direitos básicos de existência são pré-requisitos para uma vida minimamente organizada por uma rotina saudável e qualificada para prover 
suporte emocional a fim de um bom desenvolvimento cognitivo-emocional e físico/corporal para todo e qualquer indivíduo. No entanto, não é possível descartar o fato de que “...cada indivíduo também se configura como um ator social, definido ao mesmo tempo pelo espaço social no qual se insere e pela consciência de agir sobre esse espaço" (GERHARDT, 2006, p. 2450).

Esta questão foi elucidada numa pesquisa sobre o itinerário terapêutico da população da cidade de Paranaguá, no Estado de Santa Catarina, que descreveu e analisou as práticas individuais e socioculturais de saúde em termos dos caminhos percorridos por indivíduos pertencentes a camadas de baixa renda, na tentativa de solucionarem seus problemas de saúde. Vinte famílias foram acompanhadas ao longo de seis meses permitindo aos pesquisadores compreenderem a complexidade que envolve suas situações de vida e os vários fatores de ordem individual e coletiva que guiam seus comportamentos diante das dificuldades em situação de adoecimento.

Esta noção, central a este estudo, mostrou-se pertinente, pois associa a utilização que os atores sociais fazem de suas condições materiais e imateriais, em função das percepções que eles constroem dos problemas e dificuldades aos quais estão submetidos, recompondo e reinterpretando estes problemas. Além disso, tem o mérito de permitir o diálogo entre o que, na existência de um indivíduo ou de um grupo provém de fatores contextuais problemáticos, sejam eles materiais, sociais ou culturais, e as interpretações e combinações que o indivíduo faz em função de suas próprias percepções, de seus objetivos e de sua capacidade em formular um projeto de vida (GERHARDT, 2006, p.2452).

Nessa perspectiva, independente do contexto, a dialética entre o indivíduo e seu contexto sociocultural jamais deve ser ignorado. Cada um de nós tem uma forma de interpretar e construir a própria situação de vida, e estas situações terão variações nos diferentes estratos socioeconômicos. 
Sem desconsiderar essas complexas variações, Giddens (2002) aponta para três características do indivíduo ontologicamente inseguro: 1. Pode carecer de um sentimento consistente de continuidade biográfica, na qual nenhuma "narrativa" contínua possa ser sustentada na temporalidade da existência; 2. Fica sujeito a um ambiente exterior cheio de mudanças, e, neste caso, a pessoa está obsessivamente preocupada com os medos possíveis para sua existência, e paralisa em termos de ação prática, onde o autor chama essa condição de "morte íntima" - perde a condição de manter o casulo protetor; 3 . A pessoa deixa de desenvolver ou sustentar a confiança em sua autointegridade, [...] "como nos outros casos uma sensação de que a espontaneidade viva do eu se tornou uma coisa morta, sem vida" (GIDDENS, 2002, p. 55).

O autor apresenta nesses contextos, sujeitos desprovidos de autonomia para ser e existir rumo a autorrealização e que pode culminar na sensação de morte existencial. São condições que ferem a perspectiva de uma vida mais autônoma e emancipada, possivelmente com maior risco de manter-se no esforço contínuo de existir ou subexistir - de acordo com os recursos materiais e imateriais - e assim, deixar sua marca identitária no tempo-espaço.

A condição do indivíduo ontologicamente inseguro pode o impelir para experiências frustradas na caminhada para subjetivação, se o mesmo desconhece a autenticidade e o valor de seus desejos. $\mathrm{O}$ eu reflexivo não encontra oportunidades de reconhecer sua pessoidade e potência/talento nas multiplicidades de contextos para a manifestação do "eu", do "eu consigo mesmo" e do "eu com o outro". Seriam indivíduos privados de experiências da expressão de sua subjetividade e singularidade com menor oportunidade de se autorrealizarem. No avanço deste contexto, para um 
indivíduo que se descobre em um corpo adoecido, no qual sua práxis do dia-a-dia será diretamente afetada, este terá um desafio a mais a ser enfrentado:

O controle regular do corpo é um meio fundamental através do qual se mantem uma biografia da autoidentidade; e, no entanto, ao mesmo tempo o eu esta quase sempre "em exibição" para os outros em termos de corporificação. A necessidade de manejar esses dois aspectos do corpo simultaneamente, [...], é a principal razão porque uma sensação de integridade corporal - de que o eu esta seguro "no" corpo - esta tão intimamente ligado à apreciação regular dos outros (GIDDENS, 2002, p. 59).

O corpo que projeta uma imagem social se sustenta na alta modernidade em uma aparência e postura não definidas, pois também se constitui em um corpo reflexivo apoiado na aparência, postura e sensualidade (GIDDENS, 2002, p. 95). São características que se somam ao corpo na interação com os diversos meios do tempoespaço local e global e exigem uma autoidentidade coerente nesses diversos planos. Porém, um corpo ameaçado pela contingência do adoecimento corre o risco de não responder às demandas externas, às expectativas alheias e nem mesmo às atividades cotidianas a contento. Provavelmente, demandará maior esforço do sujeito para responder e manter a imagem social construída frente as solicitações do mundo moderno, especialmente os padrões normativos de saúde a serem sustentados.

Para, além disto, encontram-se as situações de doenças sem perspectiva de cura, nas quais o sujeito precisará de recursos emocionais internos ainda mais consistentes como forma de enfrentamento dos estigmas sociais fruto do adoecimento e morte iminente. Kellehear, um grande estudioso contemporâneo da história da morte social, parece concordar com Morin (1988), quando afirmou que quanto maior for a consciência da morte maior será a afirmação da identidade: "nem sempre se definiu o fim do morrer na morte biológica, mas sim no momento da morte da identidade da 
pessoa...” (KELLEHEAR, 2016, p. 39). Na corda bamba da morte social, fica sob responsabilidade do próprio indivíduo "tentar coordenar o processo biológico durante um período em que os demais ainda lhe atribuem um valor social, econômico ou político", e resistir à sensação de estar à deriva no curso dos desafios de seguir com sua biografia (KELLEHEAR, 2016, p. 435).

Independente da classe social, todos os indivíduos buscam deixar registrado sua história, uma forma de seguir com uma identidade ultravida. Esse esforço os acompanha por toda vida até a morte e independe da condição de saúde, ainda que esteja na iminência da morte. Kellehear (2016) aponta para questões de ordem existenciais que afligem todo e qualquer indivíduo que se depara com a finitude:

Esse reconhecimento da iminência do fim inaugura um ciclo mental de reflexões frequentemente constituído de análise da vida, esclarecimento dos valores, experiências de crise, meditações sobre ganhos e perdas e negociações em torno ao medo pessoal, à tristeza, à solidão ou ao dar sentido (KELLEHEAR, 2016, p.38).

Porém, ainda que a afirmação da identidade venha a ocorrer com qualquer indivíduo independente da classe social, um aspecto pode distinguir o êxito no registro identitário-biográfico no decorrer da vida, e, especialmente na finitude, já que este momento é marcado por fortes e aflitas mudanças na condição de vida. Lançando mão da teoria de Giddens (2002), a segurança ontológica iniciada nas relações primordiais, poderia ser um forte condicionante para um comportamento que oferecesse melhor resposta psicoemocional diante de um fato dessa envergadura. Essa reflexão aponta para os desafios da alta modernidade que nos leva à sensação de insegurança permanente, incluindo a sensação de morte iminente.

No entanto, a consciência sobre uma doença grave e sem perspectiva de cura, diz respeito a um fato que, ao ser atestado biologicamente, demandará uma resposta 
vivencial diretamente ligada ao estilo de vida do sujeito, as condições socioculturais que o envolve e seu particular designer comportamental frente ao novo desafio. Todos esses atributos, que amparam e regem o desempenho biográfico descreverão as escolhas e propósitos do sujeito até sua finitude. Portanto, a condição social irá minimamente ampará-lo, rumo à afirmação da identidade, no timing enquanto morrente. Como explica Kellehear (2016, p.435), “o timing da morte está na questão cultural de ajustar o tempo em um contexto biográfico mais amplo do que simplesmente os últimos dias e hora. Esse desafio de programar o morrer da pessoa no curso da vida em geral".

Em uma sociedade que emprega o "ter" como valor de tempo relacionado ao ciclo econômico, buscar "ser" na perspectiva de um sujeito adoecido e que não corresponde às demandas e valores socioculturais modernos, exigirá do indivíduo um esforço sobremaneira. Especialmente do indivíduo ontologicamente inseguro e que deve buscar mecanismos internos para seguir em frente.

A este período incerto da finitude, entre o adoecimento e a morte, não se pode precisar. Seria um valor de timing que vai além de questões técnicas empreendidas na etapa terminal da morte, como por exemplo, as diretivas antecipadas (testamento vital) amplamente discutidas na medicina paliativa. Kellehear (2016) enfatiza a importância de estudos do timing em termos biográficos, para um tempo de finitude que muitas vezes não geram certezas para traçar reações de assistência, como no caso de doenças como AIDS, em que em sua extemporaneidade "envergonha e estigmatiza tais pessoas morrentes, porque elas partem sem nenhuma característica social redentora que contribua para quaisquer preocupações da sociedade com a economia e o poder" (KELLEHEAR, 2016, p.436). 
Ainda que este autor, ressalte o estigma social provocado pelo envelhecimento, pelas doenças como a AIDS e doenças degenerativas, as quais podem, muitas vezes, implicar em um passar de meses e anos em um processo morrente solitário, ele não se afasta das questões sociais que não podem ser negligenciadas e que ultrapassam diagnósticos médicos precisos, e, ainda, toda preocupação com a morte bem administrada do ponto de vista clínico.

Um estudo norte-americano recente feito com 10.932 pessoas com mais de 50 anos de idade constatou que a saúde ruim e a invalidez têm relação inversa com o status socioeconômico. Os pobres ficam mais doentes e mais inválidos quando envelhecem. Mais pessoas são internadas em casas de repouso do mundo todo, perdendo seus lares e seus jardins, o círculo de amizades e a privacidade, a autonomia e muito de seus direitos cívicos (KELLEHEAR, 2016, p. 369).

No Brasil, o status socioeconômico pode ser considerado fator de risco para as doenças crônicas associadas às dificuldades de acesso ao sistema de saúde e ao controle inadequado de doenças como hipertensão e diabetes, levando às doenças com alto índice de mortalidade como Insuficiência Renal Crônica (NUNES et al., 2014, p. 70).

Não obstante, existem particularidades que diferem daqueles apontados por Kellehear (2016), quando se dirige aos institucionalizados. Pois as pessoas com Insuficiência Renal Crônica, ainda que possam se encontrar em condição de extrema fragilidade clínica, seguem com a vida cotidiana entrecortada por idas aos ambulatórios e internações hospitalares, sem uma indicação precisa de timing de finitude da vida, podendo se prolongar ou encurtar, dependendo das variáveis socioculturais do sujeito, nível de rede de suporte e assistência.

O timing pode favorecer o suporte e promover estratégias mais eficazes de apoio ao sujeito morrente, tanto pela equipe de saúde quanto família, desde que se respeite a forma como cada um lida com a condição de finitude. 
Toda a tese sociológica acerca da morte é que sua perspectiva impele as pessoas a agirem contra, a favor, ou ao lado da morte - elas são obrigadas a atuar para se acomodar física, cultural, política e espiritualmente a ela (KELLEHEAR, 2016, p.338).

Esta observação vale tanto para uma pessoa que está na iminência da morte, quanto àqueles que o circundam - familiares ou profissionais da saúde entre outros. Independente da pré-disposição do indivíduo, tanto psíquica, emocional e até mesmo culturalmente para lidar com sua finitude, aceitando-a ou não, ele deve ter o direito de ser amparado em toda a sua jornada, independente do timing, com políticas públicas que o ajude a se acomodar da melhor forma nesse processo. Ele não deveria se sentir envergonhado por não mais corresponder às expectativas da sociedade moderna que muitas vezes lhe sequestra o desejo e dignidade de seguir sua jornada biográfica. Não atentar para essa realidade é atestar o fracasso das políticas públicas sociais.

As mortes indignas na atual idade cosmopolita representam não uma falha das conquistas tecnológicas, e sim - e não há modo delicado de exprimi-lo - uma falha moral e social em prover de modelos satisfatórios de assistência social os morrentes nas margens econômicas do mundo (KELLEHEAR, 2016, p. 454).

Sinto que os profissionais de saúde, enquanto agentes de mudança social e da saúde em busca de uma sociedade mais justa e igualitária, tem o dever de atuar frente aos direitos sociais, tanto daqueles duramente alcançados quanto daqueles a serem conquistados, compreendendo que a bandeira "viver até morrer" diz respeito a algo maior e mais amplo que meramente atender aos desejos do sujeito e minimizar suas pendências quando este já se encontra no leito de morte. 


\section{O Lazer como Afirmação da Vida até a Morte}

Todo o conjunto de reflexões até então apresentado aponta para a necessidade humana de afirmação da identidade quanto mais esta se apropria da consciência de sua condição mortal. Seria um estado inelutável diante daquilo que nos torna impotentes e por isso a necessidade de seguir desempenhando uma série de atividades, fruto da constatação de nossa impermanência no mundo. Quanto mais afazeres, mais afirmação da identidade, maior sensação de imortalidade, ainda que a morte seja reconhecida como fato irrevogável.

Na modernidade tardia, a sensação de instabilidade social e econômica, provoca a angústia e/ou ansiedade por conta das incertezas sobre o futuro, se aproximando da sensação de morte eminente. Os riscos ambientais marcados pelo industrialismo, as guerras e doenças seguem como grande ameaça a civilização, nesse sentido as atividades e hábitos cotidianos podem ser uma resposta frutífera às angustias vividas pela insegurança contemporânea em meio a um mundo globalizado. O contato com essa realidade, ao encarar o panorama dos efeitos da modernidade tardia, pode ser duro demais para sujeitos ontologicamente inseguros. Manter uma biografia coerente e autocrítica diante da realidade social e de seus múltiplos desdobramentos requer uma estrutura psíquica que suporte as crises existenciais que possam surgir no caminho. Morin (1988) apresenta esse alerta por meio do ócio, já que este oferece o tempo da reflexão e de tomada de consciência de "quem sou" ou "quem não sou" até a morte. Giddens (2002) fala sobre os desafiadores momentos de contato com a realidade, nos quais o "eu reflexivo" em meio a construção de um autoidentidade consistente dependerá dos processos psicológicos de formação do eu, a fim de fornecem parâmetros ou não para a reorganização deste eu diante da apreciação da realidade. Ambas 
reflexões alertam para o perigo de que os indivíduos se deixem levar pela angústia diante da realidade incerta, se projetando para uma armadilha de um fazer obsessivo, perdido de sentido, pouco conectado com sua essência. Este perigo não exclui a atividade de lazer.

O lazer, apresentado por vários autores dentro da perspectiva da influência da cultura de massa e do mercado de consumo, tem sido discutido por autores contemporâneos de maneira crítica tanto no contexto global, como no nacional (LIPOVETSKY; SERROY, 2011; MARCELLINO, 2007; GOMES e ELIZALDE, 2012). Esta visão sobre o lazer torna-se vital quando estudado pelo prisma existencialista. Foi o que os autores Puke e Marcellino (2013) se propuseram em um estudo no qual ressalta, entre filósofos existencialistas, as contribuições de Albert Camus para compreender o lazer como análise da condição humana na contemporaneidade. Os autores afirmam que esta abordagem

( )...inaugura a possibilidade de construção de sentidos que vinculem o homem a suas reais necessidades sociais e subjetivas, que por ora, são capazes de desconstruir o muro cultural das banalidades e imposições que cerceiam a vida cotidiana (PUKE; MARCELLINO, 2013, p. 3).

A partir da construção do conceito do "absurdo" traçado por Camus, o filósofo apresenta o termo "ausência de sentido", quando busca romper com as ilusões humanas da vida que transcendente a morte e, na medida da tomada de consciência da finitude intransponível, dar vazão a uma impetuosa afirmação da vida. Os autores seguem apontando que Albert Camus, nesse raciocínio, destaca que a atividade da consciência se afirma na esfera do cotidiano quando reconhecemos a inutilidade de alguns de nossos hábitos e preceitos tidos como verdadeiros (PUKE; MARCELLINO, 2013). Seriam os 
momentos da vida em que há colisões com a realidade, deslocando os indivíduos de um estado condicionado de ações e mecanicamente sustentado por hábitos. Mas, Camus ${ }^{7}$, (1989, citado por PUKE; MARCELLINO, 2013, p. 13) acrescenta: “é um despertar de um sono que constrói um terreno decisivo para a consciência, tanto para o enfrentamento, quanto na escolha da renúncia à vida". Ou seja, o sentimento de absurdidade ou o deparar-se com a realidade existencial de nossa condição mortal pode gerar uma resposta de desistência da vida, ou por outro lado, no "extremo do despertar", , a sua retomada a partir de um novo sentido. A ressignificação seria fruto de uma ação revolucionária compreendida por Camus (2013) como uma das dimensões essenciais do homem. A revolta seria um movimento que surgiria "como uma reivindicação de clareza e unidade" (CAMUS, 2013, p.39).

Seguindo o pensamento de Camus, uma colisão existencial gerada pela consciência do timing limitado pelo adoecimento, conduziria para possibilidades ou de reinvenção ou desistência de si mesmo no processo de reconhecimento de tal facticidade. Seria a possibilidade de construir um novo sentido de vida no tempo da terminalidade a partir da "observância do absurdo, ou seja, na constatação da ausência de sentido dos papéis sociais que reproduzimos na vida cotidiana" (PUKE; MARCELLINO, 2013, p. 25).

Se os papéis executados descrevem um designer biográfico da forma de ser e estar no mundo, o tempo de finitude pode apresentar-se como um tempo de reflexão e seguir ou para um colapso do que até então foi desenhado como identidade ao longo da vida. Ou, por outro lado, pode despertar a necessidade de afirmar ainda mais a

\footnotetext{
${ }^{7}$ CAMUS, A. Mito de Sísifo: Ensaio sobre o Absurdo. Rio de Janeiro: Guanabara, 1989. 102 p.

${ }^{8}$ Terminologia empregada por Camus em Mito de Sísifo: Ensaio sobre o absurdo (1989)
} 
identidade constituída como um signo de autorreconhecimento e o reconhecimento daqueles que nos rodeiam.

É sob esta perspectiva que apresento o lazer, como um possível campo fértil de reconhecimento dos papéis até então desempenhados, e de seu manejo ou não como tempo de autorreflexão no decorrer da vida e na finitude.

Este tempo da reflexão aponta que, as vivências de lazer podem dar lugar a manifestações produtivas, alinhadas com a essência do ser e seu potencial criativo. Estendo este potencial para além do criativo das produções artísticas, mas refiro a uma vida como o próprio fenômeno criativo, como elemento plástico e matéria viva de transformação e desta forma, transformação do mundo.

[...] o lazer pode assentar-se na compreensão da liberdade e paixão, cujas as atitudes possibilitam a criação de sentido autêntico para existência. Assim cabe aqui a relação com os conteúdos artísticos do lazer, pressupondo o uso do tempo disponível para a fruição estética, tanto pela produção, quanto pela apreciação (PUKE; MARCELLINO, 2013, p. 2013).

Cabe contextualizar que, a discussão dos autores em questão não se refere ao tempo de finitude, mas ao tempo do ócio como propício para gerar reflexão e autoexpressão gerando outro sentido para o desempenho do lazer que não aquele delineado nos moldes capitalista e padrões de consumo:

\footnotetext{
A possibilidade de escolha das atividades e o caráter "desinteressado" de sua prática são características básicas do lazer. No entanto, o que se observa, muitas vezes, são práticas compulsivas, ditadas por modismos, ou denotadoras de "produtividade". Valoriza-se a performance, o produto e não o processo de vivência que lhe dá origem (SILVA et a.l, 2011, p.29).
}

O tempo criativo relegado para o depois, ou seja, para o tempo disponível depois das obrigações, é distinto do tempo do timing de vida fruto da finitude por adoecimento. Esse tempo impactado pelo adoecimento não reflete exatamente uma escolha pessoal, 
como o ócio, mas geralmente é concebido como uma fatalidade no curso de nossa existência, que pode assim como o ócio, gerar um tempo de reflexão.

Sendo o ócio compreendido por vários pensadores como um tempo criativo, mas que também pode gerar reflexões que culminem em angústia existencial, Kellehear (2016) faz uma interessante provocação que tensiona com os pensamentos dos outros autores aqui apresentados: a de que as atividades rotineiras ou os hábitos cotidianos que nos distanciam da "insegurança existencial", pode refletir uma visão privilegiada de existência, e que, para tal afirmação, seria necessário evidências etnográficas. O autor chama atenção para a desigualdade de classe e seus reflexos, pois nem todos desfrutam de uma vida próspera o suficiente, a ponto de poder gozar de distrações intelectuais do berço a sepultura (KELLEHEAR, 2016).

Não podemos ignorar que as péssimas condições de trabalho que ainda rondam uma sociedade nos moldes capitalista trazem consequências desastrosas para seu próprio desenvolvimento. Ao perpetuar práticas abusivas de trabalho, sem o menor compromisso com a responsabilidade social, a sociedade capitalista desvela a precariedade no entendimento sobre os valores humanos e fere o direito a uma vida mais autônoma e com maior possibilidade de autorrealização. É possível que indivíduos privados de gozar de experiências de produção criativa, de autoconhecimento e de autorreflexão, por razões socioeconomicas, ou frágil condição psicoemocional ou qualquer outra condição, apresentem maior dificuldade de lidar com o timing da finitude. O tempo de produção criativa, de lazer ou ócio, que antes não foi garantido como usufruto, troca sua roupagem para um tempo que impõe seu valor incontinente. No entanto, o timing da finitude é difícil de quantificar precisamente, o que pode tornar esse período, indubitavelmente, um período de convite para a autorreflexão. 
E se o lazer, dentro da perspectiva do pensamento existencialista, pode proporcionar experiências autênticas, de produções criativas e mais afinadas com os desejos essenciais de nossa vida, ele também pode ser um espaço para experimentações e afirmações da identidade no tempo de finitude. Mas não podemos desconsiderar o fato de que o sujeito que vivencia o processo de terminalidade, é um ser social e, portanto, "não totalmente livre de coações e normas de conduta social" (MARCELLINO, 2010, p. 27).

Pode ser que, diante das demandas do mundo capitalista, as atividades cotidianas que geralmente encontram-se nas amarras de um modelo cultural de consumo demarcando o estilo de vida contemporâneo, corram o risco de não serem diferentes daquelas desempenhadas no período da finitude. Isso significa dizer que as escolhas de atividades de lazer neste momento em especial não necessariamente seriam mais refinadas. É imperativo, que nesses tempos modernos que infringe ao lazer um valor banal não caiamos na ingenuidade nem nos meandros poéticos que assuntos como a morte pode nos conduzir, emprestando a esta um sentido carregado de romantismo como se todo e qualquer mortal ao vivenciá-la, se trajasse de um espírito pleno em sabedoria e desapego. Sem dúvida, este caminho muito se prestaria a diminuir a angústia ao falar sobre este tema, mas um posicionamento crítico-reflexivo com bases etnográficas se inclinaria a prestar-nos maior contribuição sobre o tema e seguirmos em profundidade sobre a importância do direito ao lazer desempenhado ao longo da vida até a morte. 


\section{Considerações Finais}

O lazer na perspectiva de pessoas na finitude constituiu-se como a linha condutora de toda construção teórica desta pesquisa. Tal linha agregou os conceitos do pensamento complexo, que compreendem o sujeito que deseja produzir vida, apesar da morte. Na maneira como essa construção teórica foi apresentada, percebemos que o indivíduo, ao realizar o lazer, produz vida e afirma a identidade até a morte; ao constatar sua condição de impermanência e de ser morrente, esforça-se em existir no mundo e para o mundo. Giddens (2002) acrescenta que, na modernidade tardia, o desafio de manter a autoidentidade exigirá de todos nós certa resiliência, diante das colisões com a realidade, frente a uma sociedade com perspectivas futuras incertas, o que também pode ser sentido como morte. Nesse sentido, seguirmos com nossa jornada biográfica irá requerer, de nós, profundo entendimento de quem somos e aonde queremos chegar. Tal jornada, rumo à autorrealização, dificilmente terá êxito, se não nos predispormos ao tempo da reflexão e do autoconhecimento e se não reconhecermos e fizermos as pazes com nossa condição mortal, para pensarmos, com profundidade, em uma vida com sentidos e significados afinados à nossa existência. A vida encontrará um objetivo guiado pelos desejos essenciais, que devem e podem se manifestar com maior evidência, dentro de cada um, se, para isso, se sujeitarem a experiências autorreflexivas. Esses momentos podem ser criados e reivindicados, no decorrer de nossas vidas, dentre eles o momento de lazer. É um exercício que reflete nosso nível de autonomia para governar os próprios interesses, expressos ao manifestarmos nossas escolhas por lazeres a serem garantidos como um direito cidadão, enquanto estivermos vivos. $\mathrm{O}$ ato de escolher tem como base uma função identitária, de caráter emancipatório: fazer valer os desejos, na saúde, na doença, ou em qualquer momento da 
vida, até os últimos dias. Mas, antes de tudo, é preciso que os indivíduos se reconheçam naquilo que desejam, frente a todas as influências socioculturais contemporâneas, regidas por uma lógica capitalista e de consumo, que se aproveita das distrações, para guiar os interesses. Desfrutar de uma vida de produção criativa, oportunizada de vivências que correspondam aos desejos, até a finitude, pode se revelar como um instrumento de forte resistência ao que a cultura moderna tenta impor como valor. Do contrário, há o risco de sucumbir à condição de sujeitos morrentes, saudosos de oportunidades não vividas, ou vividas, porém, apartadas de consistência e significado.

\section{REFERÊNCIA}

CAMUS, A. Mito de Sísifo: Ensaio sobre o Absurdo. Rio de Janeiro: Guanabara, 1989. 102 p. apud (citado por) PUKE, N; MARCELLINO, N. C. O lazer existencial: uma possibilidade de resposta para o absurdo. Licere., v.16, n.3, p. 1-17., set., 2013.

O mito de Sísifo. 10. ed. Rio de Janeiro: Record, 2013, 160 p.

GERHARDT, T.E. Itinerários terapêuticos em situações de pobreza: diversidade e pluralidade. Cad. Saúde Pública, Rio de Janeiro, 22(11):2449-2463, nov, 2006. Disponível em: http://www.scielosp.org/pdf/csp/2006.v22n11/2449-2463. Acesso em: 05 set. 2018.

GIDDENS, A. As consequências da modernidade. 2.ed. São Paulo: UNESP, 1991.180 p.

GIDDENS, A. Identidade e modernidade. Rio de Janeiro: Zahar Ed., 2002. 233 p.

GOMES, C.; ELIZALDE, R. Horizontes Latino-americanos do Lazer. Horizontes Latino americanos del ocio. Belo Horizonte: Editora UFMG, 2012. 343p.

KELLEHEAR, A. Uma história social do morrer. São Paulo: Editora UNESP, 2016. $588 \mathrm{p}$.

KIERKEGAARD. S.The concept of dead, Londres, Macmillan, 1944. 99 p. apud GIDDENS, A. Identidade e modernidade. Rio de Janeiro: Zahar Ed., 2002. 233 p

KUBLER-ROSS, E. A morte: um amanhecer. São Paulo: Pensamento Ed. 2015. 110 p. 
KÜBLER-ROSS, Elisabeth. Sobre a Morte e o Morrer. 4. ed. São Paulo: Martins Fontes, 1969.

KÜBLER-ROSS, Elisabeth. Morte - estágio final da evolução. 2. ed. Rio de Janeiro: Record, 1975.

KÜBLER-ROSS, Elisabeth. Perguntas e respostas sobre a Morte e o Morrer. São Paulo: Martins Fontes, 1979.

KÜBLER-ROSS, Elizabeth. A morte: um amanhecer. São Paulo: Pensamento, 1991. [2]

KÜBLER-ROSS, Elisabeth. A roda da vida: memórias do viver e do morrer. Rio de Janeiro: GMT, 1998. Social Construction of Identity.

LIPOVETSKY, G.; SERROY, J. La cultura-mundo. Respuesta a uma sociedad desorientada. Barcelona: Anagrama. In: Mediaciones Sociales, 2010, p. 165170 .

MARCELLINO, N. C. Contribuições de autores clássicos modernos e contemporâneos para os estudos do lazer. Licere, belo horizonte, v. 13, n. 4, dez. 2010.

MARCELLINO, N.C. Algumas aproximações entre lazer sociedade. Rev. Iberoamericana, v.1, n.2, mai-set. 2007.

MORIN, E. O homem e a morte. 2. ed. Mem Martins: Publicações Europa-América, $1988.326 \mathrm{p}$

MORIN, E. A noção de sujeito. In:

A cabeça bem feita: repensar a reforma, reformar o pensamento. 3. ed. Rio de Janeiro: Bertrand Brasil, 2001a. p. 117-128.

MORIN, E. O método II: a vida da vida. Porto Alegre: Sulina, 2001b. 433 p.

MORIN, E. Ciência com consciência. 8. ed. Rio de Janeiro: Bertrand Brasil, 2005. 350 p.

MORIN, E. Introdução ao pensamento complexo. Porto Alegre: Sulina, 2006. 120 p.

NUNES, M. B. et al. Perfil epidemiológico de pacientes renais crônicos em programa dialítico. Rev enferm, v. 8, n.1, p. 69-76, jan. 2014.

PUKE, N; MARCELLINO, N. C. O lazer existencial: uma possibilidade de resposta para o absurdo. Licere, v. 16, n. 3, p. 1-17, set. 2013.

RICOEUR, P. Vivo até a morte: seguido de fragmentos. São Paulo: Editora WMF Martins Fontes, 2012.97 p

ROLNIK, S. Toxicômanos de identidade. In: LINS, D. (Org.). Cultura e subjetividade. Saberes nômades. Campinas: Papirus Ed., 1997. p.19-24 
RUSSEL, B. O elogio ao Ócio. 4. ed, Rio de Janeiro: Sextante ed., 2002. 183 p.

SILVA, D. A. M. et al. Importância da recreação e do lazer. Brasília: Gráfica e Editora Ideal, 2011. 52 p.

\section{Endereço das Autoras:}

Claudia Franco Monteiro

Centro Educacional

Av. Getúlio Guaritá, 159 - Abadia

Uberaba - MG - 38.025-180

Endereço Eletrônico: Claudia.monteiro@uftm.edu.br

Cristiane Miryam Drumond de Brito

EEFFTO/UFMG

Av. Pres. Antônio Carlos, 6627 - Campus - Pampulha

Belo Horizonte - MG - 31.270-901

Endereço Eletrônico: cdrumonddebrito@gmail.com

Raquel de Magalhães Borges

Campus avançado de Governador Valadares

Universidade de Juiz de Fora. Rua São Paulo, 745, Centro

Governador Valadares - MG - 25.010-180

Endereço Eletrônico: Raquel.borges@ufjf.edu.br 